\title{
Usefulness of the Modified LRINEC Score in the Treatment of Patient with Deep Neck Infection
}

\author{
Jeong Hwan Moon \\ Department of Otorhinolaryngology-Head \& Neck Surgery, Dankook University College of Medicine, Cheonan, Korea
}

\section{심경부감염 환자 치료에 있어서 Modified LRINEC 점수의 유용성}

문 정 환

단국대학교 의과대학 이비인후-두경부외과학교실

Received October 31, 2014

Revised November 18, 2014

Accepted November 19, 2014

Address for correspondence

Jeong Hwan Moon, MD, PhD

Department of Otorhinolaryngology-

Head \& Neck Surgery,

Dankook University

College of Medicine,

201 Manghyang-ro, Dongnam-gu,

Cheonan 330-715, Korea

Tel $+82-41-550-3974$

Fax $+82-41-556-1090$

E-mail drmjh7979@naver.com
Background and Objectives Deep neck infection can occur at any age and is a potentially life-threatening diseases. However, an early recognition of aggravating infections is clinically difficult. In this study, we aimed to determine the Modified Laboratory Risk Indicator for Necrotizing Fasciitis (M-LRINEC) scores to predict aggravating deep neck infections.

Subjects and Method We retrospectively analyzed 72 patients with deep neck infection from January 2010 and December 2012 in a tertiary hospital. Differences in patient characteristics, radiographic findings, LRINEC scores, and M-LRINE scores were compared between the non-surgical group and the surgical group.

Results The mean M-LRINEC scores were 4.35 and 1.39 in the surgical group and non-surgical group, respectively. Significant differences between the two groups were found in age, size of abscess, multiple spaces involvement, air collection, and mediastinitis.

Conclusion The M-LRINEC score is an useful indicator that signals the need to initiate early surgery and also to predict aggravating deep neck infections.

Korean J Otorhinolaryngol-Head Neck Surg 2015;58(2):115-9

Key Words Deep neck infection - LRINEC score · Necrotizing fasciitis · Treatment.

\section{서 론}

심경부감염 환자의 치료에 있어 가장 중요한 것은 합병증 발생 가능성을 미리 예측하고 조기에 수술적인 치료가 필요 한 경우를 선별하여 수술적인 치료가 늦어져 발생할 수 있는 심각한 합병증을 예방하는 것이다. 하지만 경부는 복잡한 구 조로 되어 있고 심경부에 발생한 염증을 이학적 검사를 통해 그 정도를 판단하는 데에는 어려움이 있다. 2004년에 괴사성 근막염을 혈액학적 검사 결과에 따라 감별하고자 백혈구, 혈 색소, 나트륨, 당, 크레아티닌, C-반응성 단백질의 수치를 이용 하여 괴사성 근막염에 혈액학적 위험지표를 점수화한 Laboratory Risk Indicator for Necrotizing Fasciitis(LRINEC) 점수가 처음 보고되었고 괴사성 근막염을 조기에 발견하는 데
도움이 된다고 하였으나 ${ }^{1)}$ 심경부에 발생하는 괴사성 근막염의 조기 진단에는 큰 도움이 되지 못한다는 연구가 있었다. ${ }^{2)}$ 혈액 학적 검사 중 저알부민혈증이 급성기 질환에 예후와 연관이 있 다는 연구가 있어,4) 이에 저자들은 심경부감염 치료에 있어 조 기에 올바른 의사결정을 도울 수 있는 객관적 지표로 기존의 LRINEC 점수에서 저알부민혈증을 추가한 Modified LRINEC (M-LRINEC) 점수를 제안하고 이의 유용성에 대해 알아보고 자 하였다.

\section{대상 및 방법}

대 상

2010년 1월부터 2012년 12월까지 병원 이비인후과에서 심경 
부감염으로 진단받고 입원치료를 시행한 184 명의 환자를 대상 으로 연구를 진행하였다. 그 중 편도 주위나 침샘에 국한된 농 양만을 가졌거나 결핵, 이물, 외상, 악성종양으로 인해 발생한 농양으로 입원한 환자를 제외한 72 명을 대상으로 후향적 연구 를 진행하였다. 대상 환자는 신체 검진, 기저질환, 혈액학적 검 사, 방사선학적 소견을 바탕으로 이비인후과 전문의의 판단에 따라 수술 여부를 결정하였으며 수술 치료군 $(n=42)$ 과 비수술 치료군 $(\mathrm{n}=30)$ 으로 나누어 비교 분석하였다.

\section{환자 요소 평가}

수술 치료군과 비수술 치료군에서 연령, body mass index (BMI), 흡연, 음주, 당뇨병의 유무가 유의한 차이를 보이는지 분석하였다. BMI는 체중 $(\mathrm{kg}) /$ 신장 $\left(\mathrm{m}^{2}\right)$ 으로 계산하였으며 흡 연과 음주는 입원 당시의 의무기록을 검토하여 유무 여부로 구분하였다. 당뇨병의 유무는 현재 경구 투약 중이거나 인슐린 제제를 투여 중인 환자와 입원하여 당뇨병으로 진단된 환자를 당뇨병이 있는 것으로 분류하였다.

\section{영상학적 검사}

대상 환자는 모두 입원시 경부전산화단층촬영(CT)을 시행하 였으며 농양의 가로, 세로, 높이를 측정하여 그 중 최장경을 농양 의 크기로 하였다. 감염부위는 후인두공간, 내장혈관공간, 부인 두공간, 하악하공간, 이하선공간, 편도주위공간, 전장근막공간 및 종격동으로 나누어 침범된 부위가 다발성인지를 판단하였 고 CT상 공기 저류나 종격동염이 관찰되는지를 확인하였다.

\section{Modified LRINEC 점수}

본 연구에서 제안하는 Modified LRINEC(M-LRINEC) 점수에서는 기존의 LRINEC 점수에 albumin이 $3.5 \mathrm{~g} / \mathrm{dL}$ 미 만일 때를 2점, 이상인 경우를 0점으로 추가하여 적용하였다 (Table 1). LRINEC 점수와 M-LRINEC 점수를 적용하여 수 술적 치료와 괴사성 근막염과의 연관성을 비교 분석하였다.

\section{통계 방법}

통계 분석은 SPSS version 18(SPSS Software, SPSS Inc., Chigaco, IL, USA)을 이용하였다. 인구학적 요소와 수술 여 부의 상관관계를 파악하기 위해 카이제곱 및 독립표본 t검정 을 시행하였고, M-LRINEC 점수의 민감도와 특이도를 기존 LRINEC 점수와 비교해보기 위해 receiver operating characteristic(ROC) curve를 시행하였다. 유의 수준은 0.05 미만을 의미 있는 것으로 판단하였다.
Table 1. Modified Laboratory Risk Indicator for Necrotizing Fasciitis score

\begin{tabular}{lcc}
\hline Variable & Value & Points \\
\hline C-reactive protein, $\mathrm{mg} / \mathrm{L}$ & $<150$ & 0 \\
White blood cell, $\times 10^{3} / \mu \mathrm{L}$ & $\geq 150$ & 4 \\
& $15-25$ & 0 \\
& $>25$ & 1 \\
Hemoglobin, g/dL & $>13.5$ & 2 \\
& $11-13.5$ & 0 \\
Sodium, $\mathrm{mEq} / \mathrm{L}$ & $<11$ & 1 \\
& $\geq 135$ & 2 \\
Creatinine, $\mathrm{mg} / \mathrm{dL}$ & $<135$ & 0 \\
Glucose, $\mathrm{mg} / \mathrm{dL}$ & $\leq 1.6$ & 2 \\
Albumin, $\mathrm{g} / \mathrm{dL}$ & $>1.6$ & 2 \\
& $\leq 180$ & 0 \\
& $>180$ & 1 \\
& $\geq 3.5$ & 0 \\
& $<3.5$ & 2 \\
\hline
\end{tabular}

Table 2. Demographic factor related to surgical management

\begin{tabular}{lccc}
\hline & $\begin{array}{c}\text { Non surgical group } \\
(\mathrm{n}=42)\end{array}$ & $\begin{array}{c}\text { Surgical group } \\
(\mathrm{n}=30)\end{array}$ & p-value \\
\hline M:F & $27: 15$ & $19: 11$ & 0.934 \\
Age & $45(3-83)$ & $56(1-78)$ & 0.016 \\
BMl & $23.7 \pm 3.4$ & $23.2 \pm 3.2$ & 0.543 \\
Alcohol & $21(50 \%)$ & $9(30 \%)$ & 0.090 \\
Smoking & $18(43 \%)$ & $11(37 \%)$ & 0.597 \\
DM & $3(7 \%)$ & $6(20 \%)$ & 0.104 \\
\hline
\end{tabular}

BMI: body mass index, DM: diabetes mellitus

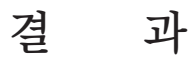

\section{환자 요소 및 영상학적 분석}

수술 치료군과 비수술 치료군에서 남녀 비율은 유의한 차이 를 보이지 않은 반면 수술 치료군의 평균 나이가 56세로 비수 술 치료군의 45세에 비해 유의하게 높았다. BMI, 음주, 흡연, 당뇨병의 유무에 따라 두 군을 비교 분석해 보았을 때 유의한 차이는 없었다(Table 2).

수술 치료군과 비수술 치료군의 전산화단층촬영을 비교해 보았을 때, 농양의 크기는 각각 $2.6 \pm 12.0 \mathrm{~cm}, 1.74 \pm 8.1 \mathrm{~cm}$ 로 수술 치료군에서 유의하게 크기가 컸다 $(p=0.001)$. 수술 치료군 의 70\%에서 여러 공간에 농양이 발생하였고 이는 비수술 치료 군에 비해 유의하게 많았으며 $(p=0.037)$, 염증 내 공기가 보이 거나 종격동염이 동반되어 발생한 경우도 수술 치료군에서 모 두 유의하게 높았다( $p=0.008,0.001)$ (Table 3).

전체 환자에서 LRINEC 점수와 M-LRINEC 점수의 비교 LRINEC 점수의 평균값은 수술 치료군에서 3.23 , 비수술 치 
료군에서 1.36으로 수술 치료군에서 유의하게 높았다 $(p=0.003)$. M-LRINEC 점수는 알부민 수치를 확인할 수 있었던 총 48 명의 환자를 대상으로 비교하였으며 수술 치료군은 4.35, 비 수술 치료군은 1.39 로 LRINEC 점수와 마찬가지로 유의하게 수술 치료군에서 점수가 높았다 $(p=0.005)$ (Fig. 1). 이 두 군의 점수로 $\mathrm{ROC}$ curve를 구해 각각의 점수의 민감도와 특이도를 비교해 보았다. LRINEC 점수의 area under the curve(AUC) 는 0.694( $p=0.005)$ 인 반면에 M-LRINEC 점수의 AUC는 0.780 ( $p=0.001)$ 으로 M-LRINEC 점수가 LRINEC 점수에 비해 더 우수한 것을 확인하였다(Fig. 2). 이를 바탕으로 수술적 치료 가 필요한지 여부를 위한 cut-off value를 구해보았다. M-LRINEC 점수 4점을 기준으로 했을 때, 민감도 $58.8 \%$, 특이도 $90.3 \%$, 양성 예측도 $71.4 \%$, 음성예측도 $79 \%$ 를 보였으며 본원에서 치
료받은 환자 중에서 실제 4점 이상일 때 유의하게 수술을 더 많 이 시행한 것을 확인하였다( $p=0.002)$ (Fig. 3).

\section{괴사성 근막염 환자에서 LRINEC 점수와 M-LRINEC 점수의 비교}

수술 치료를 시행받은 환자 중 수술 소견으로 심경부 괴사성 근막염으로 진단된 환자와 괴사성 근막염이 아닌 것으로 확인 된 환자를 나누어 LRINEC 점수와 M-LRINEC 점수를 비교 해보았다. 총 30 명의 수술 치료군 중 괴사성 근막염으로 진단 된 환자는 10 명이었고 이 환자들의 LRINEC 점수는 4.80으로 괴사성 근막염이 아닌 환자의 점수인 2.45보다 높았으나 통계 적으로 유의한 차이를 보이지는 않았다 $(p=0.061)$. 반면 술 전 알부민 수치를 알았던 총 17 명의 수술 환자 중 괴사성 근막염

Table 3. CT findings related to surgical management

\begin{tabular}{|c|c|c|c|}
\hline & Non surgical group $(n=42)$ & Surgical group $(n=30)$ & $p$-value \\
\hline Abscess size $(\mathrm{cm})$ & $1.74 \pm 8.1$ & $2.6 \pm 12$ & 0.001 \\
\hline Multiple space involvement & $19(45 \%)$ & $21(70 \%)$ & 0.037 \\
\hline Air collection & $1(2 \%)$ & $7(23 \%)$ & 0.008 \\
\hline Mediastinitis & $0(0 \%)$ & $8(31 \%)$ & 0.001 \\
\hline
\end{tabular}

Fig. 1. Comparison between LRINEC score and Modified LRINEC score. Both LRINEC and M-LRINEC score marked significantly higher value in SG than NSG. And M-LFINEC score made the difference between the two groups much higher than LRINEC score. NSG: non surgical group, SG: surgical group, LRINEC score: Laboratory Risk Indicator for Necrotizing Fasciitis score, M-LRINEC score: Modified LRINEC score.

Fig. 2. Comparison of receiver operating characteristic (ROC) curves between Laboratory Risk Indicator for Necrotizing Fasciitis (LRINEC) score and Modified LRINCEC (M-LRINCEC) score. ROC curves for sensitivity and specificity of the LRINEC score and M-LRINCEC score are illustrated below. Area under the curve (AUC) of MLRINCEC score marked higher value than LRINEC score.
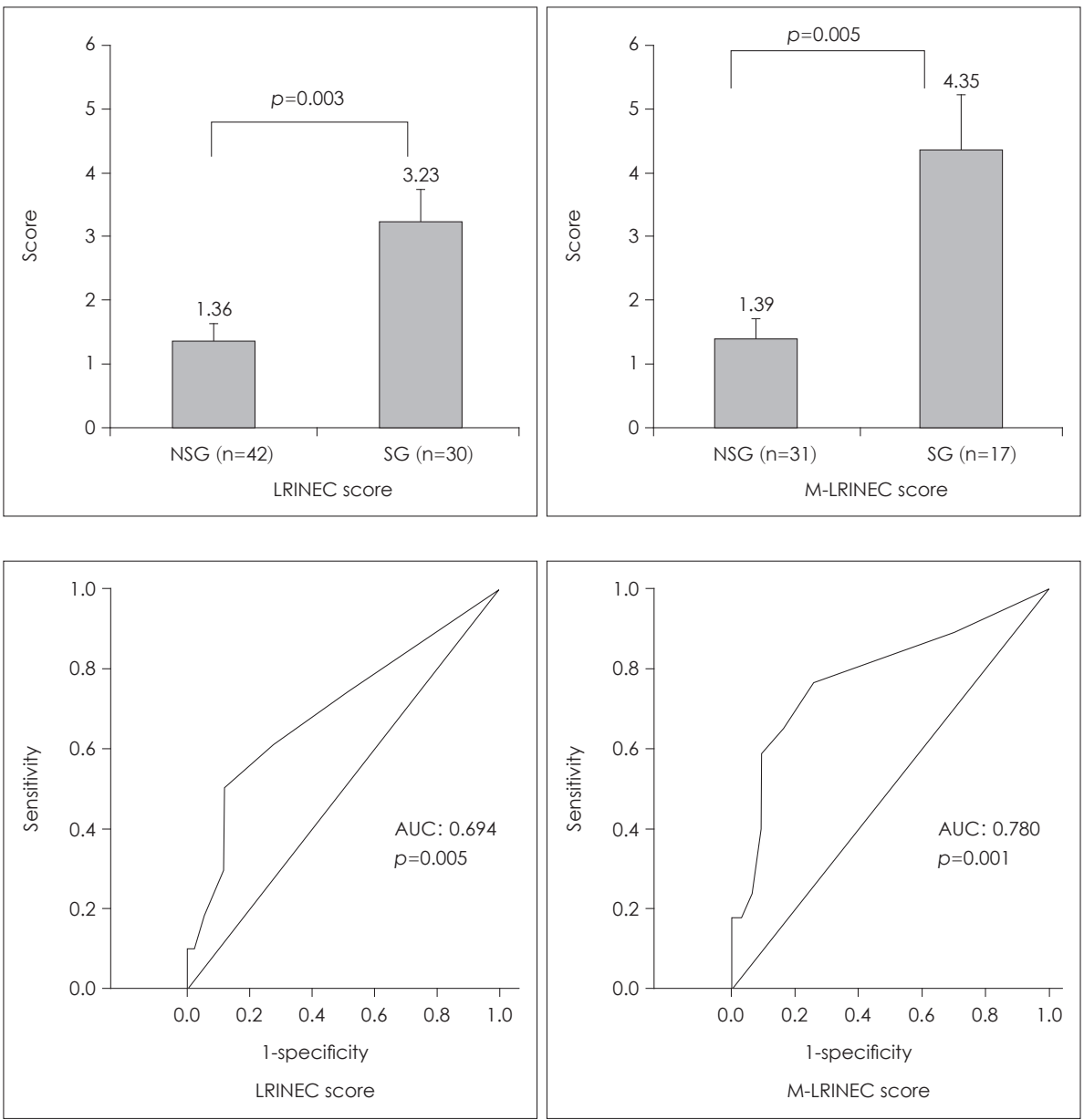
으로 진단된 환자는 5명으로 M-LRINEC 점수는 7.8로 괴사 성 근막염이 아닌 환자의 점수 2.92 보다 유의하게 높은 것을 관찰할 수 있었다( $p=0.045$ )(Fig. 4).

\section{고 찰}

심경부공간은 경부 근막으로 둘러싸인 복합적인 구조로 되 어 있어 임상적으로 염증의 범위나 진행 정도를 판단하기가 쉽 지 않아 수술적인 치료가 늦어져 유병기간이 길어지고 심각한 합병증이 발생할 가능성이 잠재해 있다.5) Boscolo-Rizzo 등하

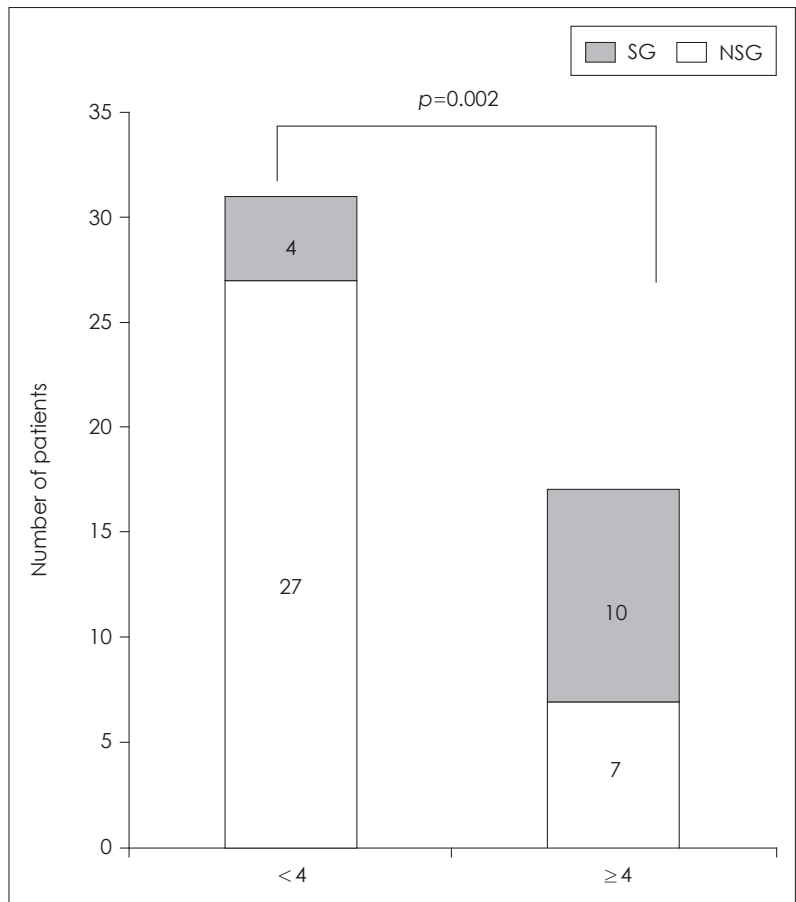

Fig. 3. Distribution of treatment according to the M-LRINEC score. When M-LRINEC score was more than 4 points, surgical treatment was more favorable. NSG: non surgical group, SG: surgical group. M-LRINEC: Modified Laboratory Risk Indicator for Necrotizing Fasciitis.
의 연구에 의하면 365 명의 심경부감염 환자에서 $38.1 \%$ 에서 수 술적인 배농이 필요했고 $18.4 \%$ 에서는 치명적인 합병증이 발생 했다고 보고하였다.

많은 연구에서 영상의학적 소견을 통해 수술적인 치료를 결 정하고 있는데 CT상에서 종격동염이나 공기음영이 있는 관찰 되는 경우, 심경부 공간을 두 개 이상 침범한 경우에는 수술적 인 치료가 대부분 필요하였고 농양의 크기는 Choo 등기 $3 \mathrm{~cm}$ 이상일 경우 수술적인 치료를 고려하도록 하였고 본 연구에서 도 수술적인 치료를 시행한 군에서 $2.6 \mathrm{~cm}$ 로 비슷한 결과를 보였다. 하지만 농양의 크기만을 가지고 수술적인 배농술을 결정하는 데 있어 농양의 크기가 $3.5 \mathrm{~cm}$ 미만인 경우 위양성 이 $25 \%$ 이상에서 나타날 수 있고, ${ }^{8} 3.5 \mathrm{~cm}$ 미만이면서 농양 주변 경계 조영이 $50 \%$ 미만으로 되는 경우에 환자의 약 반수 에서 수술시 농양이 관찰되지 않았고 항생제 치료만으로 호 전되었다는 보고가 있다." $\mathrm{Woo}$ 등 ${ }^{10)}$ 은 심경부감염이 완전한 농양보다는 불완전 농양에 형태로 보이는 경우가 더 많아 농 양 부위와 봉와직염 부위를 포함하여 병변의 크기를 정하고 치료 방향을 결정하는 것이 필요할 수 있다고 하였다.

심경부 공간에서 비정상적으로 공기 음영이 관찰되거나 ${ }^{11,12}$ 종격동염 소견인 보인 경우에는 조기에 적극적인 배농술이 필 요할 수 있는데 ${ }^{13)}$ 본 연구에서도 공기음영을 보인 1예를 제외 하고는 모두 수술적인 치료가 필요하였다.

여러 연구에서 혈액학적 검사를 바탕으로 심경부감염의 치 료 방향을 제시하고자 하고 있지만 다양한 임상양상에 적용 하기는 어렵고 조기에 수술적인 치료를 결정하기에는 보다 구 체적인 지표가 필요하다. Wall 등 ${ }^{4)}$ 은 괴사성 연부조직감염에 서 진단적 목적으로 처음 혈액학적 검사 결과를 사용하였으며, Wong 등이 혈액학적 검사를 좀 더 체계화한 괴사성 근막염 에 위험지표를 만들었고 이것을 점수화하여 연부조직 감염에 서 괴사성 근막염을 감별하는 데 유용하다고 보고하였지만 대 부분이 경부외 조직 감염을 대상으로 하여 심경부감염에 적용
Fig. 4. LRINEC score vs. M-LRINEC score in cervical necrotizing fasciitis. M-LRINEC score marked significantly higher value in cervical necrotizing fasciitis (CNF) patients much better than LRINEC score. And M-LRINEC scores between the two groups shows significant difference compared to LRINEC score. LRINEC: Laboratory Risk Indicator for Necrotizing Fasciitis, M-LRINEC: Modified-LRINEC.
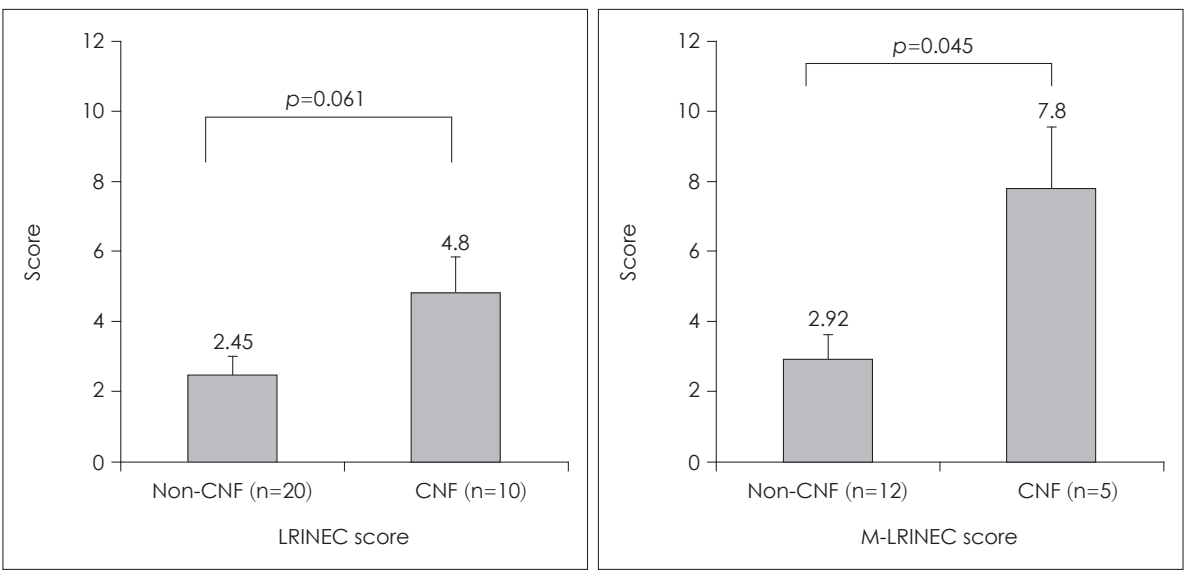
하기는 제한점이 있었다. Thomas와 Meyer ${ }^{2}$ 가 경부 괴사성 근막염을 감별하는 데 적용해 보았지만 심경부감염에서 괴사 성 근막염의 빈도가 드물기 때문에 혈액학적 검사 결과로 예 측하는 것은 유용하지 않다고 보고하였다. 본 연구에서도 LRINEC 점수를 괴사성 근막염 환자에 적용해 본 결과 경부 괴 사성 근막염 환자군에서 평균 수치가 높은 경향을 보였지만 유의한 결과를 나타내지는 못했다. 저알부민혈증은 급성기 염 증반응에 있어 중요한 인자로 작용한다. 염증이 진행되면 혈 관 투과성이 증가하고 염증 매개인자들이 활성화되어 알부민 의 혈관 밖으로 유출을 조장하게 되면서 저알부민혈증이 나타 나게 되며, 혈청 알부민은 생리적 항상성 유지에 중요한 역할 을 하는데 알부민 수치가 감소하게 되면 항상성 유지에 장애 가 발생하게 되어 염증이 진행되는 원인이 될 수 있다. 또한 알 부민은 정상적으로 교질 삼투압을 유지하는 역할을 하는데 저 알부민혈증으로 교질 삼투압이 감소하게 되면 폐, 심장 같은 여러 장기에 부종이 발생할 수 있다. 또한 여러 연구에서 저알 부민혈증이 괴사성 근막염에서 수술적인 치료 예측에 있어 도 움이 되고 ${ }^{15)}$ 급성기 질환의 예후와도 연관이 있다고 알려져 있 다. ${ }^{3,4}$ 이에 본 연구에서는 저알부민혈증을 추가하여 M-LRI$\mathrm{NEC}$ 점수를 이용하여 수술적 치료가 필요한 군에서 평균 점 수가 4.35로 비수술군에 1.39 보다 유의하게 높은 것을 확인할 수 있었고 M-LRINEC 점수가 4점 이상인 경우에 수술을 시 행한 빈도가 유의하게 높아 4점 이상인 환자들에서는 주의 깊 은 관찰이 필요할 것으로 생각된다. 괴사성 근막염 환자에서 도 적용해본 결과 유의성을 확인할 수 있었고 저알부민혈증을 추가한 M-LRINEC 점수가 심경부감염에서 괴사성 근막염 을 감별하는 데에도 도움을 줄 수 있을 것으로 생각된다. 하지 만 LRINEC 점수가 기본적으로 수술을 예측하는 인자가 아 닌 괴사성 근막염을 조기 진단하기 위해 개발한 인자이므로 결 국 수술을 결정하는 독립적인 지표로 이용하기에는 제한 점이 있고 연구 대상에 수술적 치료가 필요하지 않은 환자가 포함 되어 있을 가능성이 있어 본 연구의 결과가 임상적으로 의미 있게 적용되기 위해서는 좀 더 많은 환자를 대상으로 한 전향 적 연구가 필요할 것으로 생각된다.

\section{Acknowledgments}

The present research was conducted by the research found of Dankook University in 2013.

\section{REFERENCES}

1) Wong CH, Khin LW, Heng KS, Tan KC, Low CO. The LRINEC (Laboratory Risk Indicator for Necrotizing Fasciitis) score: a tool for distinguishing necrotizing fasciitis from other soft tissue infections. Crit Care Med 2004;32(7):1535-41.

2) Thomas AJ, Meyer TK. Retrospective evaluation of laboratorybased diagnostic tools for cervical necrotizing fasciitis. Laryngoscope 2012;122(12):2683-7.

3) Vincent JL, Dubois MJ, Navickis RJ, Wilkes MM. Hypoalbuminemia in acute illness: is there a rationale for intervention? A meta-analysis of cohort studies and controlled trials. Ann Surg 2003;237(3):319-34.

4) Hedström M, Gröndal L, Ortquist A, Dalén N, Ahl T. Serum albumin and deep infection in femoral neck fractures. A study of 437 cases followed for one year. Int Orthop 1998;22(3):182-4.

5) Kim CS, Ha JH, Kim DJ, Choi IK, Park JH, Jeong YJ. Clinical study of deep neck infection: clinical analysis of a hundred cases. Korean J Otolaryngol-Head Neck Surg 1997;40(9):1325-32.

6) Boscolo-Rizzo P, Stellin M, Muzzi E, Mantovani M, Fuson R, Lupato V, et al. Deep neck infections: a study of 365 cases highlighting recommendations for management and treatment. Eur Arch Otorhinolaryngol 2012;269(4):1241-9.

7) Choo MJ, Kim JS, Kim JW, Shin SO, Cha SH. Efficacy of computed tomography for diagnosis and treatment of the deep neck infection. Korean J Otolaryngol-Head Neck Surg 1997;40(12):1826-32.

8) Maroldi R, Farina D, Ravanelli M, Lombardi D, Nicolai P. Emergency imaging assessment of deep neck space infections. Semin Ultrasound CT MR 2012;33(5):432-42.

9) Freling N, Roele E, Schaefer-Prokop C, Fokkens W. Prediction of deep neck abscesses by contrast-enhanced computerized tomography in 76 clinically suspect consecutive patients. Laryngoscope 2009;119 (9):1745-52

10) Woo JH, Cha HE, Lee JH, Gang IG, Baek MK, Kim DY. Clinical analysis of factors affecting on treatment of deep neck infection. Korean J Otorhinolaryngol-Head Neck Surg 2008;51(6):544-8.

11) Holt GR, McManus K, Newman RK, Potter JL, Tinsley PP. Computed tomography in the diagnosis of deep-neck infections. Arch Otolaryngol 1982;108(11):693-6.

12) Lille ST, Sato TT, Engrav LH, Foy H, Jurkovich GJ. Necrotizing soft tissue infections: obstacles in diagnosis. J Am Coll Surg 1996;182(1): $7-11$.

13) Mihos P, Potaris K, Gakidis I, Papadakis D, Rallis G. Management of descending necrotizing mediastinitis. J Oral Maxillofac Surg 2004;62(8):966-72.

14) Wall DB, Klein SR, Black S, de Virgilio C. A simple model to help distinguish necrotizing fasciitis from nonnecrotizing soft tissue infection. J Am Coll Surg 2000;191(3):227-31.

15) Tsai YH, Huang KC, Shen SH, Hsu WH, Peng KT, Huang TJ. Microbiology and surgical indicators of necrotizing fasciitis in a tertiary hospital of southwest Taiwan. Int J Infect Dis 2012;16(3):e15965. 